\title{
ROMANIAN INSURANCE MARKET SUPERVISION
}

\author{
NASTASE, A[driana] R[odica]
}

\begin{abstract}
The paper presents the risk matrix based on ten key risks of Romanian insurance undertakings from their point of view. This is practically a synthesis approach based on 2010 companies' reports and the annual report of the Romanian Insurance Supervisory Commission.
\end{abstract}

Key words: insurance, risk based supervision, inherent risk, risk matrix

\section{INTRODUCTION}

The goal of this paper is to present specific risks for Romanian insurers as part of risk-based supervision process. The limitation of research consists in focusing on risk assessment, a step in risk management process and not in rating or early warning systems.

There were 43 insurance undertakings which have carried out insurance/reinsurance activities in 2010, of which 20 nonlife undertakings, 12 life insurance undertakings and 11 composite undertakings.

The total gross premiums written by insurance undertakings in 2010 on both insurance categories reached 8305 million lei; down in nominal terms by $6.36 \%$ compared with previous year, i.e. $13,26 \%$ in real terms, considering the impact of inflation.

The Romanian insurance market was still a concentrated market in 2010, as $79.17 \%$ of total gross written premiums were reported by 10 of 43 insurance undertakings (ISC, 2011). The drop in the volume of gross written premiums combined with the increase in current price GDP has led to a slight fall down in the insurance penetration rate in 2010.

The insurance penetration rate (the ratio between gross written premiums and GDP) was $1,62 \%$, with $0,18 \%$ percentage points lower than in 2009. Insurance density (the ratio between gross written premiums and the number of inhabitants) decreased with 6,15\% compared with 2009.

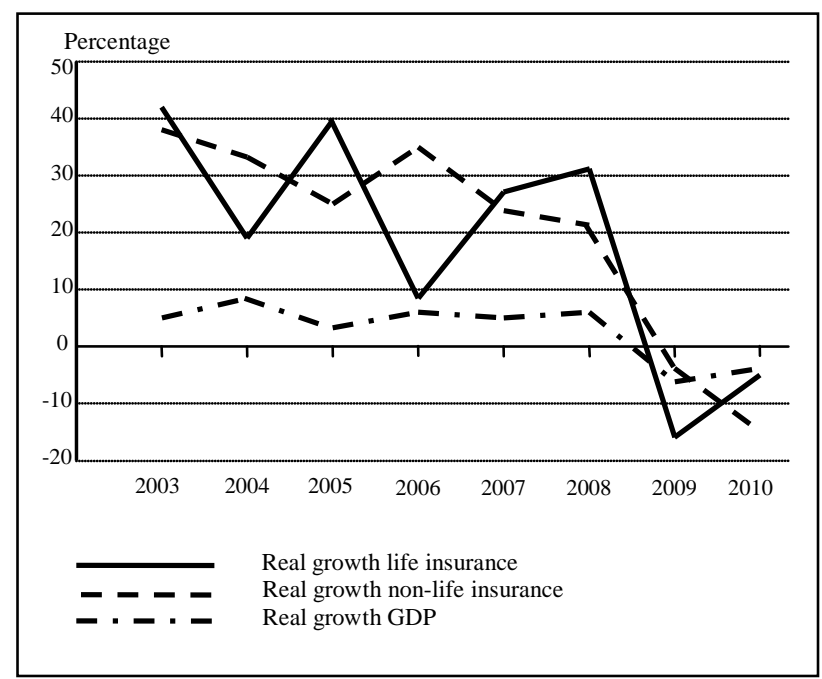

Fig. 1. Correlation between insurance market and economic growth

\section{ROMANIAN INSURANCE SUPERVISION}

The primary aim of supervision is to protect consumers, who are considered weak compared to powerful insurers, or unable to make a rational and fully informed selection of the best insurance product and the most solvent company. Moreover, because insurers receive money from policyholders (that is, premiums), before paying claims, consumers face two additional risks: a risk of mismanagement of their money, if it is not well invested or if premiums are insufficient because of initial miscalculation and a risk of abuse by insurers who might take the money and disappear or, even worse, build so-called 'Ponzi schemes' (Liedtke, 2011).

For the supervisor, it is important that the policyholders are protected, but it is important for him to ensure the stability on financial market (Nastase, 2010).

One of the main objectives of the long-term strategy established for 2005-2011 by the Romanian Insurance Supervisory Commission is changing the supervisory principle: from "compliance based" supervision to "risk-based" supervision, as a pre-requisite for the implementation of Solvency II requirements (ISC, 2011).

Risk-based supervision is a structured process aimed at identifying the most critical risks that face each company and through a focused review by the supervisor to assess the company's management of those risks and the company's financial vulnerability to potential adverse experience.

Under compliance based supervision the role of the supervisory authority is to ensure that insurers do, in fact, comply with a set of prudential rules generally written into the law (Randle, 2009). Risk based supervision requires supervisors to review the manner in which insurers are identifying and controlling risks.

Risk based supervision considers each of the risks that companies face and through a structured process identifies the risks that are most critical to the financial viability of the institution (Thompson, 2001).

\begin{tabular}{|c|c|}
\hline Compliance-based approach & Risk-based approach \\
\hline $\begin{array}{l}\text { Focus on compliance with e.g. } \\
\text { laws, taxes or quantitative } \\
\text { investment rules }\end{array}$ & $\begin{array}{l}\text { - Identifies potential risks } \\
\text { - Assesses mitigating factors } \\
\text { - Seeks proper management of } \\
\text { all risks }\end{array}$ \\
\hline $\begin{array}{l}\text { - Often rigid, detailed rules are } \\
\text { difficult to be changed to meet } \\
\text { urgent regulatory needs }\end{array}$ & $\begin{array}{l}\text { Principle-based legislation, } \\
\text { forward looking and flexible }\end{array}$ \\
\hline $\begin{array}{l}\text { - Supervisor is focus on compliance } \\
\text { with rules, not risk management }\end{array}$ & $\begin{array}{l}\text { - Incentives for supervisor to } \\
\text { strengthen risk management } \\
\text { practices }\end{array}$ \\
\hline $\begin{array}{l}\text { - Point in time focus } \\
\text { - Overlooks major risk areas } \\
\text { - No early warning system }\end{array}$ & $\begin{array}{l}\text { - Supervisors use judgment to } \\
\text { assess risk and quality of } \\
\text { management }\end{array}$ \\
\hline $\begin{array}{l}\text { - Duplicates work of auditors } \\
\text { (internal, external, IT auditors) }\end{array}$ & \begin{tabular}{|l|} 
- Compliance verifications are \\
performed by auditors, \\
duplication of work is removed
\end{tabular} \\
\hline
\end{tabular}

Tab. 1. Risk-based vs. compliance-based supervision 


\section{TOP 10 INHERENT RISKS AND RISK MATRIX}

The inherent risks which were described by insurance undertakings in their reports are:

Issue no. 1. Slow collection of premiums, with large receivable balances over 90 days, which lead to a limitation in the admissibility of assets and to liquidity issues.

Issue no. 2. Increasing volume of recoveries receivables on paid claims, which could lead to certain expected recoveries not being recovered and to a deterioration in the actual loss ratios (impact on equity and solvency margin) and to liquidity issues.

Issue no. 3. There is recent diversification with innovative insurance covers in new lines of business, without a proven expertise in these areas, which could lead to inadequate business strategies and to erroneous underwriting decisions.

Issue no. 4. Insufficient specialization of the personnel as per the jobs held (underwriting vs. claims) and as per lines of business (motor vs. new lines of business), thing which might lead to a breach in the internal control system (segregation of duties) and to decisions being taken driven by the lack of experience in the new lines of business.

Issue no. 5. There are fully delegated collection processes, which could lead to increased fraud from insurance brokers, delays in the collection of premiums and ultimately could lead to liquidity issues.

Issue no. 6. Standardization, automatic calculation of the recoveries expected (as a percentage out of gross claims) without a proper evaluation of the recovery expected, which might lead to an increase of the current loss ratios (impact onto the capital and solvency margin).

Issue no. 7. There are fully outsourced recoveries collection process, which could lead to increased fraud from third parties and collectors and delays in the collection.

Issue no. 8. Recoveries expected are not reduced with a certain percentage to anticipate the collection taxes payable to collectors, leading to an underestimation of the loss ratios due to claims (impact onto the capital and solvency margin).

Issue no. 9. It exist aggressive development of the business in the motor insurance sector with small insurance premiums and high commissions, thing which might lead to the acceptance of an unprofitable business as per the motor insurance segment (focusing on the volume and not on the quality of the subscription).

Issue no. 10. Payable commissions for uncollected premiums are not accrued, thing which might lead to an over estimation of the capital and of the solvency margin.

After identification of risks it was performed the risk classification and risk assessment, in order to finally obtained the risk matrix.

\begin{tabular}{|c|c|c|c|c|}
\hline $\begin{array}{l}\text { Risk criteria } \\
\text { /aggregation } \\
\end{array}$ & $\begin{array}{l}\text { Process / } \\
\text { Activity } \\
\end{array}$ & Issue & $\begin{array}{c}\text { Risk } \\
\text { classification }\end{array}$ & $\begin{array}{c}\text { Risk to } \\
\text { Objectives }\end{array}$ \\
\hline \multirow{4}{*}{$\begin{array}{c}\text { Business } \\
\text { overview } \\
\text { and } \\
\text { performance } \\
\text { (BOP) }\end{array}$} & $\begin{array}{c}\text { Claims } \\
\text { (recoveries) }\end{array}$ & I. 2 . & $\begin{array}{c}\text { Credit } \\
\text { business risk }\end{array}$ & $\begin{array}{c}\text { Financial } \\
\text { failure }\end{array}$ \\
\hline & $\begin{array}{c}\text { Claims } \\
\text { (recoveries) }\end{array}$ & I.7. & $\begin{array}{c}\text { Operational } \\
\text { business risk }\end{array}$ & Fraud \\
\hline & Collections & I.1. & $\begin{array}{c}\text { Credit } \\
\text { business risk }\end{array}$ & $\begin{array}{c}\text { Financial } \\
\text { failure }\end{array}$ \\
\hline & Collections & I.5. & $\begin{array}{c}\text { Operational } \\
\text { business risk }\end{array}$ & Fraud \\
\hline \multirow{3}{*}{$\begin{array}{l}\text { Prudential } \\
\text { quantitative } \\
\text { requirements } \\
(\mathrm{PQR})\end{array}$} & $\begin{array}{c}\text { Claims } \\
\text { (recoveries) }\end{array}$ & I.6. & $\begin{array}{c}\text { Reserving } \\
\text { business risk }\end{array}$ & $\begin{array}{c}\text { Financial } \\
\text { failure }\end{array}$ \\
\hline & $\begin{array}{c}\text { Claims } \\
\text { (recoveries) }\end{array}$ & I.8. & $\begin{array}{c}\text { Financial } \\
\text { reporting risk }\end{array}$ & $\begin{array}{c}\text { Financial } \\
\text { failure }\end{array}$ \\
\hline & $\begin{array}{c}\text { Financial } \\
\text { statements } \\
\text { close process }\end{array}$ & I.10. & $\begin{array}{c}\text { Financial } \\
\text { reporting } \\
\text { risk }\end{array}$ & $\begin{array}{l}\text { Financial } \\
\text { failure }\end{array}$ \\
\hline \multirow{3}{*}{$\begin{array}{l}\text { Oversight } \\
\text { and } \\
\text { governance } \\
\text { (OG) }\end{array}$} & $\begin{array}{c}\text { Business } \\
\text { development }\end{array}$ & I.9. & $\begin{array}{l}\text { Underwriting } \\
\text { business risk }\end{array}$ & $\begin{array}{c}\text { Misconduct, } \\
\text { mismanage }\end{array}$ \\
\hline & $\begin{array}{c}\text { Business } \\
\text { development }\end{array}$ & I.3. & $\begin{array}{c}\text { Strategic } \\
\text { business risk }\end{array}$ & $\begin{array}{c}\text { Misconduct, } \\
\text { mismanage }\end{array}$ \\
\hline & $\begin{array}{c}\text { Segregation of } \\
\text { duties }\end{array}$ & I. 4. & $\begin{array}{c}\text { Operational } \\
\text { business risk }\end{array}$ & $\begin{array}{l}\text { Misconduct, } \\
\text { mismanage }\end{array}$ \\
\hline
\end{tabular}

Tab. 2. Inherent risks

\begin{tabular}{|c|c|c|c|}
\hline $\begin{array}{c}\text { Risk criteria } \\
\text { (Risk } \\
\text { aggregation) }\end{array}$ & Impact & Probability & $\begin{array}{c}\text { Inherent } \\
\text { risk } \\
\text { assessment }\end{array}$ \\
\hline BOP - I. 2. & Severe & Moderate High & Moderate \\
\hline BOP - I. 7. & Moderate & Low & Low \\
\hline BOP - I. 1. & Severe & Moderate High & Moderate \\
\hline BOP - I. 5. & Moderate & Low & Low \\
\hline BOP & Severe & Moderate High & Moderate \\
\hline PQR - I. 6. & Severe & High & High \\
\hline PQR - I. 8. & Severe & High & High \\
\hline PQR - I.10. & Moderate & High & Moderate \\
\hline PQR & Severe & High & High \\
\hline OG - I. 9. & Threatening & Moderate High & High \\
\hline OG - I. 3. & Threatening & Moderate High & High \\
\hline OG - I. 4. & Moderate & Moderate High & Moderate \\
\hline OG & Threatening & Moderate High & High \\
\hline
\end{tabular}

Tab. 3. Inherent risks assessment

\begin{tabular}{|c|c|c|c|c|c|}
\hline \multirow{3}{*}{ 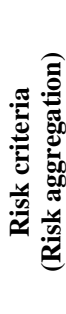 } & \multicolumn{3}{|c|}{ Inherent risk } & $\begin{array}{c}\text { Control } \\
\text { effectiveness }\end{array}$ & $\begin{array}{c}\text { Residual } \\
\text { risk }\end{array}$ \\
\hline & \multicolumn{3}{|c|}{ Assessment of inherent risk } & $\begin{array}{c}\text { Assessment } \\
\text { of control }\end{array}$ & \\
\hline & 䒿 & 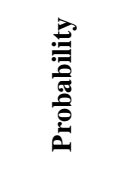 & 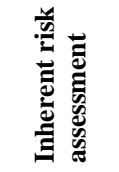 & 它 & $\begin{array}{c}\text { Residual } \\
\text { risk } \\
\text { assessment }\end{array}$ \\
\hline BOP & Severe & $\begin{array}{l}\text { Moderate } \\
\text { High }\end{array}$ & Moderate & Low & Moderate \\
\hline $\mathrm{PQR}$ & Severe & High & High & Low & High \\
\hline OG & Threatening & $\begin{array}{l}\text { Moderate } \\
\text { High }\end{array}$ & High & Moderate & Moderate \\
\hline
\end{tabular}

Tab. 4. Risk matrix

\section{CONCLUSION}

This study has a contribution to a better understanding of the risks facing the Romanian insurance undertakings. It is a source of information for local insurers who can establish better their place on the market from the risk management point of view, by using a practical approach.

In the future, the research described in this paper will be integrated in a training course focused on how insurers set up a risk management process (by embedding each activity into the overall risk management process) and how the local supervisor establish the risk profile of each insurer based on their reports, as part of the monitoring chart and surveillance annual plan.

\section{REFERENCES}

Liedtke, P.M. \& Monkiewicz, J. (2011). The future of insurance regulation and supervision, Palgrave Macmillan, ISBN-10: 0230292690, ISBN-13: 978-0230292697, U.K.

Nastase, A. R. (2010). Romanian Insurance Market and Solvency II Regime, Annals of DAAAM for 2010 \& Proceedings of the 21st International DAAAM Symposium, 20-23rd October 2010, Zadar, Croatia, ISSN 1726-9679, ISBN 978-3-901509-73-5, Katalinic, B. (Ed.), pp. 13971398, Published by DAAAM International Vienna, Vienna

Randle, T. (2009). Risk based supervision, Available from: http://siteresources.worldbank.org/FINANCIALSECTOR/ Resources/Primer14_Risk_Based_Supervision.pdf Accessed: 2011-08-31

Thompson, J. (2001). Risk based supervision of the insurance companies, An Introduction, Available from:

http://www1.worldbank.org/finance/assets/images/RiskBased_Supervision_-_Feb_21.pdf, Accessed: 2011-09-30

*** (2011) http://www.csa-isc.ro - The Romanian Insurance Supervisory Commission, Report on the insurance market and the insurance supervision in 2010, Accessed on: 201109-30 